Pathology and Clinics Received on: 01/03/2021 Accepted on: 04/08/2021

\title{
Mesenchymal Stem cells in the context of canine atopic dermatitis: A Review
}

\section{Células-tronco mesenquimais no contexto da dermatite atópica canina: uma revisão}

${ }^{1}$ REIS, Bruna Padilha Zurita Claro dos https://orcid.org/0000-0002-3863-7483

${ }^{2}$ ORGE, Iasmim Diniz

https://orcid.org/0000-0001-5935-0177

${ }^{3}$ SAMPAIO, Gabriela Louise de Almeida https://orcid.org/0000-0002-9955-258X

\author{
${ }^{1,3}$ DALTRO, Sérgio Ricardo Teixeira \\ https://orcid.org/0000-0001-9872-7280 \\ ${ }^{3.4}$ SANTOS, Ricardo Ribeiro dos \\ https://orcid.org/0000-0002-8548-0431 \\ 3.4* MEIRA, Cássio Santana \\ https://orcid.org/0000-0002-7578-3615 \\ 3.4SOARES, Milena Botelho Pereira \\ https://orcid.org/0000-0001-7549-2992
}

${ }^{1}$ Federal University of Bahia (UFBA), School of Veterinary Medicine and Animal Science, Salvador, Bahia, Brazil.

${ }^{2}$ University of Porto, Abel Salazar Institute of Biomedical Sciences, Porto, Portugal.

${ }^{3}$ Gonçalo Moniz Research Center, Oswaldo Cruz Foundation (FIOCRUZ), Salvador, Bahia, Brazil.

${ }^{4}$ SENAI Institute of Innovation in Health Advanced Systems (CIMATEC ISI SAS), University Center SENAI/CIMATEC, Salvador, Brazil.

*Mail for correspondence: cassio.meira@fieb.org.br

\begin{abstract}
Canine atopic dermatitis (CAD) is a chronic inflammatory skin disease and has a high frequency among dermatological diseases. The interaction of genetic factors, skin and environmental conditions affect the expression of the disease, developing a complex pathology. Current multimodal treatment has numerous adverse effects and variations in its efficacy and safety, demonstrating the need to develop safe and effective therapeutic resources for patients with CAD. Mesenchymal stem cells (MSCs) are multipotent cells, with special characteristics, such as self-renewal, immunomodulatory properties, and dedifferentiation, making them useful for several clinical problems. The discovery of the immunosuppressive effect of MSCs on T cells has opened the potential for new perspectives with its use as a therapeutic agent for immune diseases, such as CAD. The scarce number of research using the MSC as a treatment for CAD result in the lack of knowledge about the benefits and possible protocols to be followed for the use of this cell therapy. In this review, we highlighted the clinical studies and potential biological mechanisms of MSC-based cell therapy effects attenuating canine atopic dermatitis
\end{abstract}


compared to conventional treatment, which might lead to a safe improvement of the animal's clinical condition in a short period without causing adverse effects.

Keywords: dermatology, inflammatory, skin diseases, canine atopic dermatitis.

\section{RESUMO}

A dermatite atópica canina (DAC) é uma doença inflamatória crônica da pele e tem alta frequência entre as doenças dermatológicas. A interação de fatores genéticos, pele e condições ambientais afetam a expressão da doença, desenvolvendo uma patologia complexa. O tratamento multimodal atual apresenta inúmeros efeitos adversos e variações em sua eficácia e segurança, demonstrando a necessidade de desenvolver recursos terapêuticos seguros e eficazes para pacientes com DAC. As células-tronco mesenquimais (CTM) são células multipotentes, com características especiais, como auto renovação, propriedades imunomoduladoras e desdiferenciação, tornando-se úteis para diversos problemas clínicos. A descoberta do efeito imunossupressor das CTMs sobre as células $\mathrm{T}$ abriu o potencial para novas perspectivas com sua utilização como agente terapêutico para doenças imunológicas, como a DAC. O escasso número de pesquisas utilizando o MSC como tratamento para DAC resulta no desconhecimento dos benefícios e dos possíveis protocolos a serem seguidos para a utilização dessa terapia celular. Nesta revisão, destacamos os estudos clínicos e os potenciais mecanismos biológicos dos efeitos da terapia celular baseada em MSC que atenuam a dermatite atópica canina em comparação com o tratamento convencional, podendo levar a uma melhora segura da condição clínica do animal em um curto período, sem causar efeitos adversos.

Palavras-chave: dermatologia, doenças inflamatórias, dermatológicas, dermatite atópica canina.

\section{INTRODUCTION}

Canine atopic dermatitis (CAD) is a chronic skin disease, with severe inflammatory and pruritic condition, it is estimated that $10-15 \%$ of dogs worldwide are affected by this illness (Klinger et al., 2018; Gedon; Mueller, 2018; Santoro, 2019). The complex multifactorial nature of the disease does not allow the identification of a single etiologic factor, making the pathogenesis of the disease not entirely comprehensive and very wide. Although, factors such as an interaction of environmental allergens and genetic predisposition can be identified in the affected animals (Marsella, 2012; Santoro, 2019).

The typical treatment indicated for CAD is multimodal, consisting of the use of topical and systemic immunosuppressants and target-specific immunotherapy (Marsella, 2012; Cosgrove et al., 2013). Among immunosuppressants, glucocorticoids are the most used drugs due to their effectiveness, low cost and easy access, however, several adverse effects are present when administered on a longterm basis, which could lead to an increase in secondary skin infections, iatrogenic hyperadrenocorticism, gastrointestinal ulceration, polyuria and 
polydipsia (Klinger et al., 2018; Nuttall et al., 2019; Santoro, 2019).

Target-specific immunotherapy relies on the use of selective enzyme inhibitors Janus Kinases 1 (JAK 1 - oclacitinib) and caninized anti-interleukin 31 (anti-IL 31) monoclonal antibodies (lokivetmab). Such drugs require administration for several days (oclacitinib) or months (lokivetmab). In addition, the chronic use of these drugs is also associated with several adverse effects such as vomiting, diarrhea and increased risk of opportunistic infections (Gedon; Mueller, 2018; Klinger et al., 2018; Nuttal et al., 2019).

According to Marsella (2012) and Nuttal et al. (2019), until the present moment CAD has no cure, and the current treatments provide only momentary relief of clinical signs. In addition, no successful tests have been developed to identify the specific mechanisms that trigger the disease (Marsella; De Bennedeto, 2017) making it harder to target the most correct, effective, and least disadvantageous treatment in the long run. Therefore, the development of new therapeutic resources for CAD is extremely important, considering the disadvantages associated with the current treatment model, along with the growing need to establish an effective and safe therapy for patients.

Faced with this problem, cell therapies, such as mesenchymal stem cell (MSC) transplantation, have been demonstrating safety and efficacy in studies for the treatment of CAD (Villatoro et al., 2018; Enciso et al., 2019; Ramos et al., 2020; Voga et al., 2020). The immunomodulatory action of MSCs has generated new perspectives for its use as a therapy for immune- mediated diseases, reducing the production of inflammatory cytokines and improving the quality of life of animals with skin disorder (Daltro et al. 2020; Jiang; Xu, 2020). In this context, this review focuses on the beneficial effects of MSCs as an alternative treatment for canine atopic dermatitis.

\section{CANINE ATOPIC DERMATITIS (CAD)}

The inflammatory and pruritic skin condition caused by CAD is related to an allergic condition (Marsella; De Bennedeto, 2017). Factors such genetic predisposition, stress, defects in the skin barrier, hypersensitivity I / IV and high IgE production, due to environmental allergens, are involved in the pathogenesis of $\mathrm{CAD}$, promoting a complex multifactorial etiological character (Hensel et al., 2015; Olivry et al., 2015; Nuttal et al., 2019). In CAD, patients have a dysregulated immune response, with interaction/activation of a delicate balance between $B$ and $T$ lymphocytes (Pucheu-Haston et al., 2015a; Nuttal et al., 2019).

Initially, in acute CAD lesions, the immune response is dominated by $\mathrm{Th} 2$ (T helper 2), with IL-4, IL-5, IL-6, IL-13 and IL-31 cytokines release (Hensel et al., 2015; Olivry et al., 2016; Mineshige et al., 2018). Another cytokine that plays an important role in this stage is thymic stromal lymphopoietin (TSLP), produced by keratinocytes. TSLP induces the maturation/activation of dendritic cells (DC) and mast cells (Klukowska-Rötzler et al., 2013; Olivry et al., 2016). These series of cytokines instigate itching, inflammation of the skin and decreased integrity of the skin 
barrier that leads to the development and perpetuation of this disease (Tait Wojno; Artis, 2016). In chronic skin lesions in $\mathrm{CAD}$, however, a mixture of mediators of Th1, Th2, Th17 and Th22 cells has been described, with increased production of interferon-gamma (IFN$\gamma)$, IL-6, IL12 and granulocytemacrophage colony-stimulating factor (GM-CSF) (Jassies-Van Der Lee et al., 2014; Olivry et al., 2016; Daltro et al., 2020).

Due to the complexity of the pathogenesis, the most likely scenario is the defect in the skin barrier, allowing microbial adherence and penetration of allergenic proteins (Santoro et al., 2015; Nuttal et al., 2019). Allergens are captured by Langerhans cells, that will migrate to regional lymph nodes and present the allergens through MHC class II-linked epitopes to naive $\mathrm{CD}^{+} \mathrm{T}$ lymphocytes, generating differentiation in Th2 lymphocyte (Daltro et al. 2020). After differentiation, cytokines are released, leading to increase proliferation and maturation of $\mathrm{B}$ cells into plasma cells, that will release specific IgE against the allergen (Pucheu-Haston et al., 2015b; Saridomichelakis; Olivry, 2016). Circulating IgE binds specifically to the surface of mast cells, due to the expression of the high affinity $\operatorname{IgE}$ receptor (FceRI), inducing degranulation (Figure 1) and release of cytokines and pro-inflammatory mediators, such as histamine, tryptase, chymase, eicosanoids, leukotrienes, tumor necrosis factor alpha (TNF- $\alpha$ ) and the recruitment of eosinophils (PucheuHaston et al., 2015b; Saridomichelakis; Olivry, 2016).
In atopic dogs, qualitative and quantitative deficiencies are present in the skin barrier, especially in the ceramides and in the transepidermal water loss (TEWL) (Shimada et al., 2009). In a study by Shimada and collaborators (2009), the decrease in the amount of ceramides accelerates the increase in TEWL, which is directly proportional to the severity of the damage to the stratum corneum, clinically observable as dry skin. This clinical characteristic contributes to the penetration of pathogens and the breakdown of the skin layer integrity, which may aggravate pruritus (Olivry et al., 2011). At the beginning of CAD, cutaneous dysbiosis occurs, which favors the notable increase in the number of Staphylococcus pseudintermedius and Malassezia pachydermatis on the skin (Santoro et al., 2015; Bradley et al., 2016; Torres et al., 2017). Combined, cutaneous dysbiosis and dry skin are an incentive to establish more acute conditions in CAD.

The first clinical signs in CAD have a higher incidence between six months and three years of age (Bizikova et al. 2015; Saridomichelakis; Olivry, 2016). In the absence of pathognomonic clinical signs, the characteristics of the syndrome can be confounded with other diseases or go unnoticed (Favrot, 2015; Olivry et al., 2015). This illness can be aggravated by other allergies, such as allergic dermatitis to ectoparasite bite and tropho-allergic dermatitis, creating overlapping clinical signs (Marsella; De Bennedeto, 2017; Nuttal et al., 2019). Therefore, in general, CAD are clinically characterized by the presence of erythema, followed by itching and inflammation, with variable intensity, 
from mild to severe, according to the stage of the disease (Hensel et al., 2015; Nuttall et al., 2019).

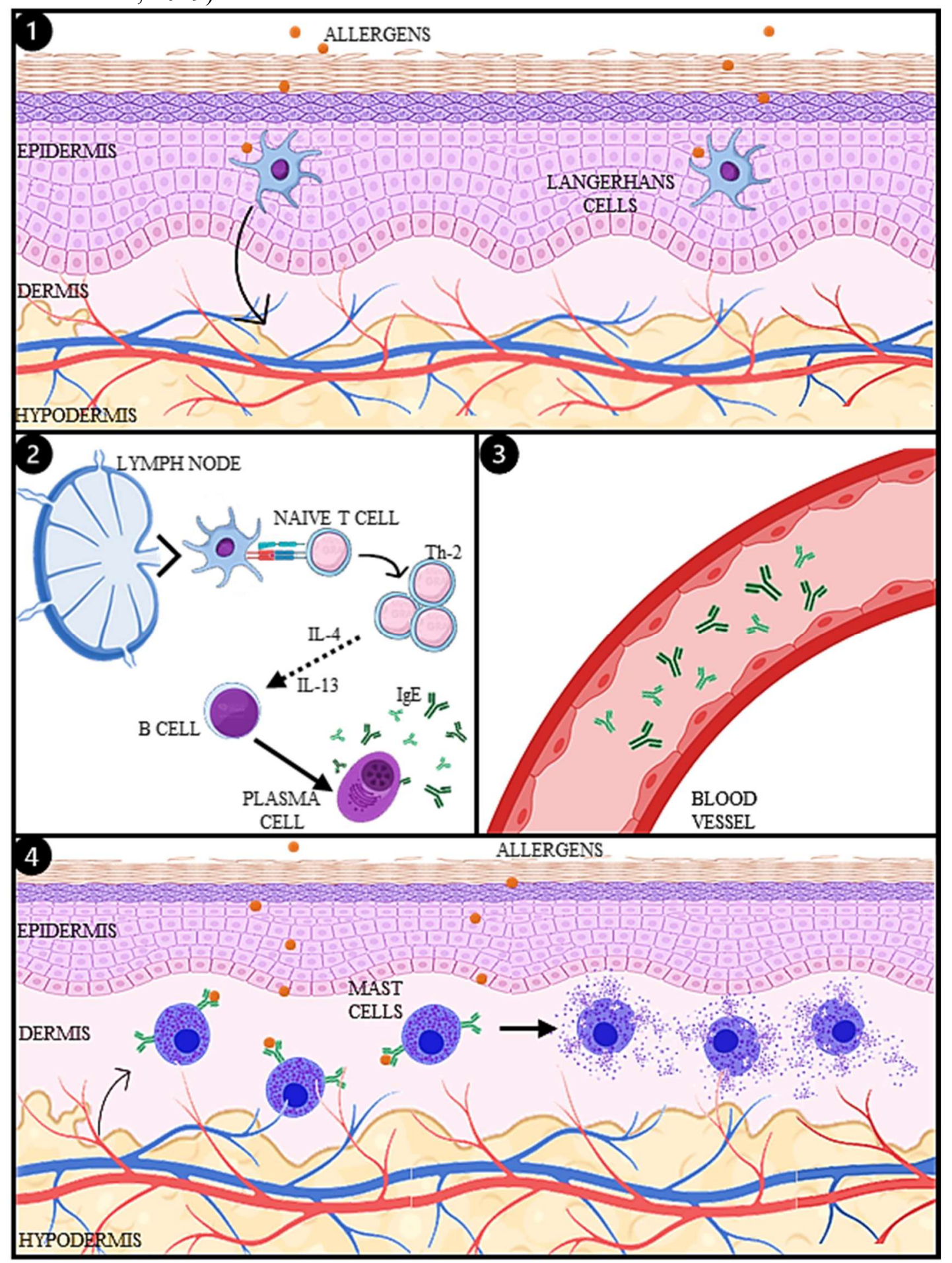

FIGURE 1. In acute CAD, the dysfunction of the skin barrier allows the penetration of allergenic proteins, captured by Langerhans cells (1). The dendritic cell will migrate to regional draining lymph 
nodes and present the allergens via MHC class II-bound epitopes to naive CD4 $+\mathrm{T}$ lymphocytes, causing polarization to a Th2 phenotype. This phenotype secretes IL-4 and IL13, which stimulate B cell maturation/proliferation in plasma cells and secrete allergen-specific $\operatorname{IgE}(2)$, released into the blood vessel (3). In the dermis, circulating IgE specifically binds to the surface of mast cells, when a second contact with allergens occurs, the mast cells are activated and degranulated, starting the clinical signs of the disease (4).

The clinical signs of CAD are mainly caused by pruritus and erythema, causing primary clinical injuries due to self-inflicted trauma, inducing alopecia, abrasions, papules, pustules, crusts, hyperpigmentation and lichenification (Marsella; De Benedetto, 2017; Ramos et al., 2020). The main affected regions are the armpits, abdomen, auricular pavilions, periocular, perioral, perianal and interdigital regions. Even though, all of these zones are rarely affected simultaneously in the same animal, except in chronic cases. (Favrot, 2015; Jensen-Jarolim et al., 2015; Nuttall et al., 2019).

The diagnosis of CAD is clinical, based on the age of clinical signs beginning, breed, clinical signs, lesion pattern according to CADESI-4 and exclusion of differential diagnoses related to pruritic diseases, such as allergy to ectoparasites, scabies, pediculosis, food hypersensitivity and cutaneous neoplasias, as lymphomas (Olivry et al. 2014; Favrot., 2015; Hensel et al. 2015). The elimination of CAD differential diagnoses, for the most part, occurs through trial and error, due to the impossibility of distinguishing the syndrome from other clinically similar dermatological diseases (Hensel et al., 2015; Nuttal et al., 2019).

Until this moment, there are no single and confirmatory diagnostic tests for $\mathrm{CAD}$, only supporting tools. Allergic tests, specific allergens, and serological panels, are options of auxiliary tests for
CAD, performed through intradermal tests, Skin prick-test and allergenspecific IgE serum (Carmona-Gil et al., 2019; Nuttal et al., 2019). However, positive reactions occur both in healthy dogs and in atopic dermatitis, not being reliable since the total serum $\operatorname{IgE}$ concentrations do not seem to have clinical relevance in the dog (Hensel et al., 2015; Jensen-Jarolim et al., 2015). Once CAD is diagnosed in the animal, the tests can be used in combination with the individual medical history for allergens treatment selection.

\section{AVAILABLE TREATMENTS FOR CAD}

The treatment of CAD is based on the identification and control of the probable factors that might be causing the disease, with a combined therapeutic approach adapted to each patient, according to age, severity of the lesions, degree of itching and duration of illness (Saridomichelakis; Olivry, 2016; Nuttal et al., 2019; Santoro, 2019). However, regardless of treatment, strategies are more effective when the animal is young and has not yet developed chronic skin changes (Saridomichelakis; Olivry, 2016; Gedon; Mueller, 2018).

Until 2016/2017, the only released drugs with proven efficacy used in CAD were immunosuppressants, mainly topical and some systemic, such as glucocorticoids and calcineurin inhibitors, like cyclosporine and tacrolimus (Gortel, 
2018). Ever since, target specific immunotherapy, drugs such selective Janus Kinases 1 (JAK 1) inhibitors (oclacitinib) and canine anti-IL-31 monoclonal antibodies (lokivetmab) have been developed to neutralize cytokines and increase tolerance to the itchy environmental allergens and inflammation (Cosgrove et al., 2013; Olivry et al., 2015; Klinger et al., 2018; Gedon; Mueller, 2018; Nuttal et al., 2019).

Glucocorticoids effectively exert numerous anti-inflammatory effects, reducing the release of Th1 cytokines, including interleukin-2 (IL-2) and interferon gamma (IFN- $\gamma$ ), and $\mathrm{Th} 2$ cytokines, such as IL-4, IL-5 and IL-13 (Maneechotesuwan, 2018). This effect provides rapid control of inflammation in atopic skin, both in acute and chronic cases, which considerably reduces itching (GORTEL, 2018). However, they have numerous adverse effects, including polyuria, polydipsia, polyphagia, obesity, iatrogenic hyperadrenocorticism, in addition to promoting an increase in bacterial and fungal infections (Olivry et al., 2015; Gedon; Mueller, 2018).

Calcineurin inhibitors (cyclosporine) form the cyclosporine-cyclophilin complex, which inhibits calcineurin phosphatase, blocks the transcription of many pro-inflammatory genes resulting in down-regulation of IL-2 and IFN- $\gamma$ (Palmeiro, 2013; Forsythe; Paterson, 2014). Although the control of clinical signs of this drug seems excellent for $\mathrm{CAD}$, the remission of clinical signs is noticeably slower when compared to other therapies and adverse effects include skin / urinary infections, hyperplastic dermatitis, viral papilloma and gastrointestinal disorders (Nuttall; Reece; Roberts, 2014; Little et al., 2015; Gortel, 2018).

The selective inhibitor of the enzyme JAK 1 (Oclacitinib) blocks the Th2 pathway and the activity of proinflammatory and pruritogenic cytokines, leading to significant inhibition of IL-2, IL-4, IL-6, IL-13 and IL-31 (Gonzales et al., 2014; Gedon; Mueller, 2018; Gortel, 2018). It is an effective drug, fast acting and has a good safety profile, but it has a high cost in relation to other therapies. Adverse effects are poorly described, such as anorexia, vomiting, diarrhea and skin infections (Cosgrove et al., 2013; Little et al., 2015; Nuttal et al., 2019). More disadvantages are attributed, among them, the minimum age of 12 months to use the drug, less efficacy when simultaneous diseases are present, likely severe inflammation, lichenification, otitis and pododermatitis (Gortel, 2018; Furue et al., 2018; Gedon; Mueller, 2018; Nuttal et al., 2019).

The canine monoclonal anti-IL-31 antibody (Lokivetmab) specifically neutralizes canine IL-31. This interleukin induces pruritus and is a proinflammatory mediator, being confirmed as a key cytokine in the development of initial skin lesions of CAD (Moyaert et al., 2017; Furue et al., 2018; Souza et al., 2018). The drug may be less effective in the presence of other diseases besides CAD, such as severe inflammation, lichenification, otitis and pododermatitis (Souza et al., 2018; Nuttal et al., 2019; Marsella et al., 2020). The treatment is considered safe, without any immediate adverse reaction, but its clinical significance is not clear at the moment (Gortel, 2018; Marsella et al., 2020). 
Currently, there is no treatment, including any of the pharmacological interventions described, with $100 \%$ effectiveness in cases of CAD. The treatment approach for each dog with atopic dermatitis must be personalized and flexible to be adjusted according to the different needs of the patient. A lifelong management plan, due to the chronicity of CAD, must be developed since atopic dermatitis has no cure. The management plan needs to be adapted for each owner and animal, as each animal may have different clinical signs.

\section{MSCS AND IMMUNOMODULATORY PROPERTIES}

Mesenchymal stem cells (MSCs) are multipotent somatic cells mainly characterized by a high in vitro proliferation capacity, fibroblastic morphology with plastic adherence in culture, ability to differentiate into adipocytes, chondrocytes, and osteocytes, low immunogenic profile, and capability to integrate and interact with the host tissue after transplant (Borghesi et al., 2019).

These cells can be isolated from diverse tissue types as bone marrow, adipose tissue, skeletal muscle, dental pulp and placenta (Williams et al., 1999; Igura et al., 2004; Romanov et al., 2005). Moreover, the expression of the surface markers CD105, CD73 and CD90, and the absence of hematopoietic markers such as CD11b, CD14, CD19, CD34, CD45, CD79, and HLA-DR are determined as essential standards to characterize MSCs (Figure 2) (Mushahary et al., 2018).
Nevertheless, isolated MSCs maintained in culture behave as a heterogeneous population with cells in different degrees of self-renewal capacity and differentiation potential (Wilson et al.,2019). Therefore, other surface antigens, including CD10, CD13, CD29, CD44, CD49, CD54 and CD166 are also considered MSCs markers (Najar et al., 2020). As an effort to overcome that characterization heterogeneity, the International Society for Cellular Therapy (ISCT) recently recommended that the acronym MSC should be accompanied by the origin of the tissue source used to isolate the cells, as the expression of surface markers can be modified by the culture conditions, passage number and tissue origin of the MSCs. That type of identification could help to determine the specific properties of the different sorts of isolated MSCs (Samsonraj et al., 2017; Viswanathan et al., 2019).

Beyond those aspects, an important characteristic associated with the potential clinical use of MSCs is to treat a broad range of diseases, mainly related to injured tissues and immune-mediated diseases. The MSCs have the potential to modulate the immune system in a multimodal way, interacting and suppressing the immune cells by the releasing of trophic factors, cytokines, antioxidant agents and cell-to-cell communication (Wei et al., 2013; Glenn; Whartenby, 2014; Golchin et al., 2019). Moreover, MSCs express low levels of the major histocompatibility complex (MHC) class I and have no significant expression of MHC class II molecules and CD40 costimulatory molecules CD80 and CD86, which participate in the activation of $\mathrm{T}$ cells. This immunophenotypic profile allows their escape of immune surveillance and promote their privileged hypoimmunogenic / immunological status after transplant into 
host tissue (Wang et al., 2019; Van Megen et al., 2019).

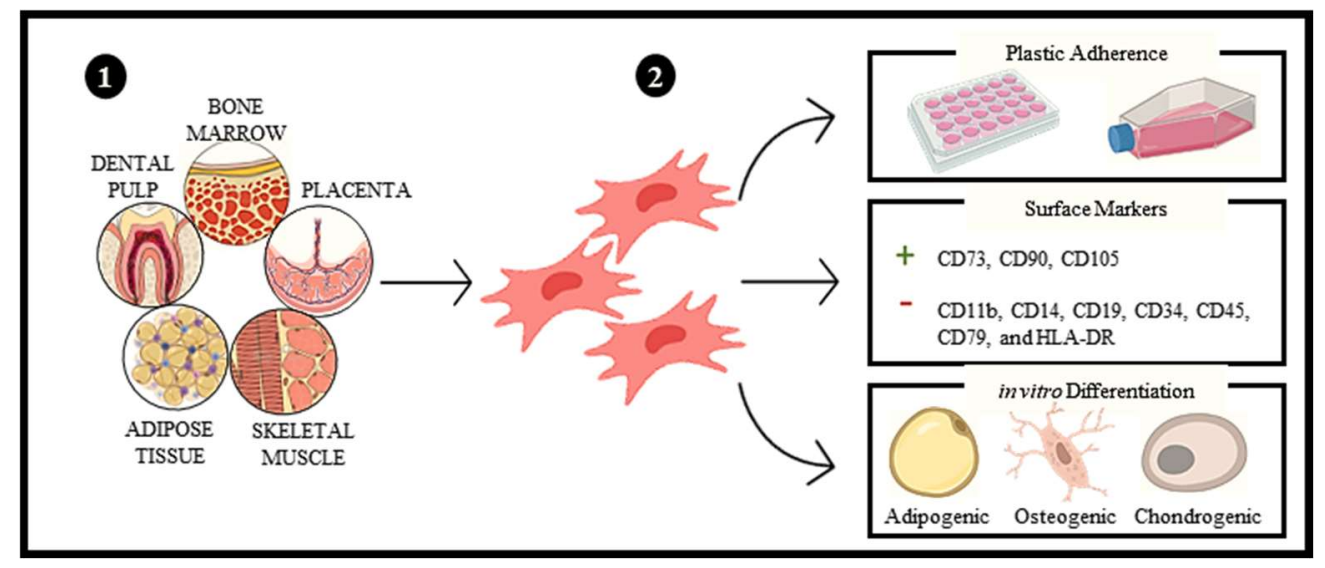

FIGURE 2 MSCs can be isolated from bone marrow, placenta, skeletal muscle, adipose tissue, and dental pulp (1). Characterized by fibroblastic morphology with plastic adherence in culture, expression of the surface markers CD105, CD73 and CD90, absence of CD11b, CD14, CD19, CD34, CD45, CD79, and HLA-DR, and ability to differentiate into adipocytes, chondrocytes, and osteocytes (2).

The immune modulation promoted by MSCs includes both innate and adaptive related responses. In the innate immune system, MSCs can promote the polarization of M2 phenotype macrophages through COX-2-PGE2 pathway, suppress mast cells degranulation and production of TNF- $\alpha$, inhibits the activation of natural killer cells $(\mathrm{NK})$, reduce production of proinflammatory cytokines, and induce the expression of anti-inflammatory cytokines as IL-10 (Golchin et al., 2019). In addition, MSCs are able to decrease activation of the complement system by cell surface expression of the complement inhibitors CD46, CD55 and CD59 (Le Blank et al., 2015).

Modulation of the adaptive immune system by MSCs also plays an important role in the therapeutic effects of these cells. Several studies report that MSCs can inhibit the proliferation of $\mathrm{T}$ cells

and induce CD8+ cells apoptosis (Jiang et al., 2020). Other findings show that MSCs can suppress excessive B cells, proinflammatory Th1 and Th17 cells activation, also improving regulatory $\mathrm{T}$ cells (Tregs) proliferation, favoring the development of Th2 anti-inflammatory populations (Najar et al., 2016). The presence of pro-inflammatory cytokines as IFN- $\gamma$, TNF- $\alpha$, IL- $1 \alpha$ and IL- $1 \beta$ has a pivotal role in MSCs immune modulation effects. These cytokines induce the expression of iNOS and COX-2 by MSCs, suppressing T cells by nitric oxide and prostaglandin E2 (PGE2) exposition (Jiang et al., 2020). Furthermore, MSCs produce a variety of chemokines and adhesion molecules, such as receptor 3 ligands of chemokine 
CXC (CXCR3), C-C type 5 chemokine receptor (CCR5) ligands, intercellular adhesion molecule 1 (ICAM-1) and vascular cell adhesion molecule 1 (VCAM-1). Such chemokines are fundamental for lymphocyte recruitment to injured sites environments (Crop et al., 2010; Li et al., 2012; Ma et al., 2014). Thereby, transplantation of MSCs as a form of treatment has the potential to balance the immune response and regulate inflammation profiles, thereby promoting the successful treatment of various immune-mediated diseases, including CAD.

\section{VETERINARY APPLICATION OF MSCS FOR CAD}

To date, clinical studies have shown efficacy in the use of MSC as a cell therapy for CAD (Villatoro et al., 2018; Enciso et al., 2019; Ramos et al., 2020; Voga et al., 2020). This line of treatment has been widely advocated, especially when MSCs are autologously isolated from bone marrow and adipose tissue (Strioga et al., 2012). However, the use of autologous transplants represents a challenge, since the animals that need MSC are sick and generally do not have minimum requirements to undergo the procedure, making the allogeneic transplant more realistic and used.

In a study by Villatoro et al., 2018, 26 dogs aged 1.5 to 10 years who suffered from refractory $\mathrm{CAD}$ in the last 12 months and did not respond to conventional therapy were evaluated. These animals received a single dose of $1.5 \times 10^{6} \mathrm{cAd}$-MSCs per $\mathrm{kg}$, allogeneic MSC derived from adipose tissue, applied via intravenous (IV) for 30 minutes. From the 26 animals involved,
22 completed the study without the need for a systemic immunosuppressant within six months after the treatment, and 3 did not need an immunosuppressant in the first three months of follow-up. Four dogs did not respond to cell therapy and additional therapies were required. None of the animals showed systemic or local adverse effects.

A second study, by Enciso et al., 2019, used 12 dogs aged 1 to 3 years, previously diagnosed with CAD, submitted to weekly intramuscular (IM) administration of $0.5 \times 10^{6} \mathrm{cAd}-\mathrm{MSCs}$ per $\mathrm{kg}$ in the pelvic femoral muscle region, for 6 weeks, at the end of the study each dog received a total of $3 \times 10^{6}$ cAd-MSCs per kg. The animals showed substantial reduction in pruritus and associated clinical signs, while no adverse reactions were observed either systemically or at the application site.

In a third study, Ramos et al., 2020, selected 16 dogs, aged between 1 and 12 years, diagnosed with CAD according to CADESI-4. They were evaluated for 82 days, and in D10, D31, and D52 received $2 \times 10^{6}$ per $\mathrm{kg}$ of cAd-MSC by the IV route. There was a significant difference in the reduction of epidermal thickness and MSCs attenuated the clinical signs of AD. Hematological, biochemical, and body temperature parameters remained within normal limits for the species with no side effects.

These three studies are the most prominent among all the clinical studies using MSC in CAD present in the literature (Table 1). They demonstrate the effectiveness of this new cell therapy, despite the use of different methods. Currently, there is no standardization in the use of MSC in CAD, and the 
necessity to standardize well established protocols is critical to reduce differences between methodologies. Such differences are highlighted when analyzing the quantities of animals used in clinical research, which makes the result unreliable, with low significance. A more reliable data analysis among standardized protocols is required in order to set the conditions to develop a new therapy that could be brought to the clinic.

Table 1. Study of MSCs Transplant for CAD Treatment

\begin{tabular}{|c|c|c|c|c|c|}
\hline $\begin{array}{l}\text { MSC tissue } \\
\text { source }\end{array}$ & Study N & $\begin{array}{l}\text { Dose of } \\
\text { treatment }\end{array}$ & $\begin{array}{l}\text { Type of } \\
\text { injection }\end{array}$ & $\begin{array}{l}\text { Principals } \\
\text { outcomes }\end{array}$ & References \\
\hline $\begin{array}{l}\text { Allogeneic } \\
\text { canine } \\
\text { adipose } \\
\text { tissue }\end{array}$ & $26 \operatorname{dogs}$ & $\begin{array}{l}1.5 \text { million } \\
\text { cells } / \mathrm{kg}\end{array}$ & $\begin{array}{l}\text { Single IV } \\
\text { injection }\end{array}$ & $\begin{array}{l}\text { - Remission of } \\
\text { CAD clinical signs } \\
\text { for at least six } \\
\text { months*. } \\
\text { - No adverse } \\
\text { events. }\end{array}$ & $\begin{array}{l}\text { Villatoro et al., } \\
2018\end{array}$ \\
\hline $\begin{array}{l}\text { Allogeneic } \\
\text { canine } \\
\text { adipose } \\
\text { tissue }\end{array}$ & 12 dogs & $\begin{array}{l}0.5 \text { million } \\
\text { cells } / \mathrm{kg}\end{array}$ & $\begin{array}{l}6 \mathrm{IM} \\
\text { injections for } \\
6 \text { weeks }\end{array}$ & $\begin{array}{l}\text { - Substantial } \\
\text { reduction in } \\
\text { pruritus. } \\
\text { - No adverse } \\
\text { events. }\end{array}$ & $\begin{array}{l}\text { Enciso et al., } \\
2019\end{array}$ \\
\hline $\begin{array}{l}\text { Allogeneic } \\
\text { canine } \\
\text { adipose } \\
\text { tissue }\end{array}$ & 16 dogs & $\begin{array}{l}2 \text { million } \\
\text { cells/kg }\end{array}$ & $\begin{array}{l}3 \text { IV injections } \\
\text { with } 21 \text { days } \\
\text { interval }\end{array}$ & $\begin{array}{l}\text { - Attenuated the } \\
\text { clinical signs*. } \\
\text { - Reduction of } \\
\text { epidermal } \\
\text { thickness. } \\
\text { - No adverse } \\
\text { events. }\end{array}$ & $\begin{array}{l}\text { Ramos et al., } \\
2020\end{array}$ \\
\hline
\end{tabular}

Intravenous, IV; Intramuscular, IM; *CADESI-4.

\section{WEIGHTING THE USE OF MSCS IN VETERINARY MEDICINE}

The use of MSC in veterinary medicine is constantly growing, both experimentally and clinically, but it is not as fast and efficient as in human medicine. Cell therapy in domesticated animals varies according to the veterinarian and the laboratory of choice, with no standardization for each species or disease, this decision being made by the professionals involved (Markoski, 2016). Unfortunately, this leads to the implementation of some animal therapies that have not been tested previously and with no proven effectiveness in vitro or in preclinical studies (Yagi et al., 2010).

In a study made by Fortie and Travis, 2011, some questions were raised about the use of stem cells in veterinary medicine. Regardless of the clinical application of the MSC, the questions are the same and include the following: (a) What is the ideal tissue to be used as a source of stem cells for each clinical application? (b) How many stem cells are needed to achieve regeneration? (c) What is the best way to transplant cells? Should they be administered locally at the injury site or intravenously? (d) Is there a need to add growth factors in 
conjunction with the transplanted stem cells for better target function / therapy? In current applications of MSC, it is unlikely that a single source of stem cells would be the best for tissue regeneration of the three different embryonic germ layers (endoderm, mesoderm, ectoderm). Very few dose-response studies have been conducted to date, and available data suggest that "more is not better". Many of these issues are closely linked, and it is evident the need for more investments, with extreme care in planning and development, for research with stem cells in the area of veterinary medicine (Fortie; Travis, 2011; Devireddy et al., 2017).

\section{CONCLUSION}

This review concludes that cell therapy with MSCs is a safe approach for the treatment of $\mathrm{CAD}$, suggested as a promising therapy for the control of this canine illness and viable for application in several species of mammals, such as humans, for sharing some aspects of the syndrome. This treatment can promote a significant improvement of the clinical picture in a short period after the cell transplant and does not trigger side effects, which is an important factor. However, it is important to continue research in this area, since it is something so new and promising in veterinary medicine, with the potential to improve the treatment of numerous diseases, due to its ability to promote tissue repair, activation of paracrine factors and immunomodulation.

\section{REFERENCES}

BIZIKOVA, P. et al. Review: Clinical and histological manifestations of canine atopic dermatitis. Veterinary dermatology, v.26 n.2, p.79-e24, 2015.

BRADLEY, C. W. et al. Longitudinal Evaluation of the Skin Microbiome and Association with Microenvironment and Treatment in Canine Atopic Dermatitis. The Journal of investigative dermatology, v.136 n.6, p.1182-1190, 2016.

CARMONA-GIL, A. M., SÁNCHEZ, J., MALDONADO-ESTRADA, J. Evaluation of Skin Prick-Test Reactions for Allergic Sensitization in Dogs with Clinical Symptoms Compatible with Atopic Dermatitis. A Pilot Study. Frontiers in veterinary science, v. 6 p.448, 2019.

COSGROVE, S. B. et al. Efficacy and safety of oclacitinib for the control of pruritus and associated skin lesions in dogs with canine allergic dermatitis. Veterinary dermatology, v.24 n.5, p.479-e114, 2013.

CROP, M. J. et al. Inflammatory conditions affect gene expression and function of human adipose tissue-derived mesenchymal stem cells. Clinical and experimental immunology, v.162 n.3, p.474-486, 2010.

DALTRO, S. et al. Mesenchymal Stem Cells and Atopic Dermatitis: A Review. Frontiers in cell and developmental biology, v.8, p.326, 2020.

ENCISO, N., AMIEL, J., PANDO, J., ENCISO, J. Multidose intramuscular allogeneic adipose stem cells decrease the severity of canine atopic dermatitis: A pilot study. Veterinary world, v.12 n.11, p.1747-1754, 2019.

FAVROT, C. Clinical signs and diagnosis of canine atopic dermatitis. In: 3. Congresso 
Latinoamericano de Dermatologia Veterinaria, Buenos Aires, Argentina, 26 November 2015 - 27 November 2015.

FORSYTHE, P., PATERSON, S. Ciclosporin 10 years on: indications and efficacy. The Veterinary record, v.174 n.Suppl 2(Suppl 2), p.13-21, 2014.

FORTIER, L. A., TRAVIS, A. J. Stem cells in veterinary medicine. Stem cell research \& therapy, v. 2 n. 1, p.9, 2011.

FURUE, M. et al. Emerging role of interleukin-31 and interleukin-31 receptor in pruritus in atopic dermatitis. Allergy, v.73 n.1, p.29-36, 2018.

GEDON, N., MUELLER, R. S. Atopic dermatitis in cats and dogs: a difficult disease for animals and owners. Clinical and translational allergy, v. 8 n.41, 2018.

GLENN, J. D., WHARTENBY, K. A. Mesenchymal stem cells: Emerging mechanisms of immunomodulation and therapy. World journal of stem cells, v.6 n.5, p.526-539, 2014.

GOLCHIN, A. et al. The Clinical Trials of Mesenchymal Stem Cell Therapy in Skin Diseases: An Update and Concise Review. Current stem cell research \& therapy, v.14 n.1, p.22-33, 2019.

GONZALES, A. J. et al. Oclacitinib

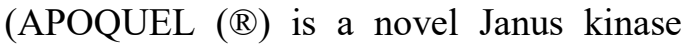
inhibitor with activity against cytokines involved in allergy. Journal of veterinary pharmacology and therapeutics, v.37 n.4, p.317-324, 2014.

GORTEL K. An embarrassment of riches: An update on the symptomatic treatment of canine atopic dermatitis. The Canadian veterinary journal $=\mathbf{L a}$ revue veterinaire canadienne, v.59 n.9, p.1013-1016, 2018.
HENSEL, P. et al. Canine atopic dermatitis: detailed guidelines for diagnosis and allergen identification. BMC Vet Res, v.11, p.196, 2015.

IGURA, K. et al. A. Isolation and characterization of mesenchymal progenitor cells from chorionic villi of human placenta. Cytotherapy, v. 6, n. 6, p. 543-553, 2004.

JENSEN-JAROLIM, E. et al. Pollen Allergies in Humans and their Dogs, Cats and Horses: Differences and Similarities. Clinical and Translational Allergy, v.5 n. $15,2015$.

JIANG, W., XU, J. Immune modulation by mesenchymal stem cells. Cell proliferation, v.53, p.1, 2020.

KLINGER, C. J. et al. Vitamin D shows in vivo efficacy in a placebo-controlled, double-blinded, randomised clinical trial on canine atopic dermatitis. The Veterinary record, v.182, p14, 2018.

LE BLANC, K., DAVIES, LC. Mesenchymal stromal cells and the innate immune response. Immunology letters, v.168 n.2, p.140-146, 2015.

LI, W. et al. Mesenchymal stem cells: a double-edged sword in regulating immune responses. Cell death and differentiation, v.19 n.9, p.1505-1513, 2012.

LITTLE, P. R. et al. A blinded, randomized clinical trial comparing the efficacy and safety of oclacitinib and ciclosporin for the control of atopic dermatitis in client-owned dogs. Veterinary dermatology, v.26 n.1, 26(1), p.23-e8, 2015.

MA, S. et al. Immunobiology of mesenchymal stem cells. Cell death and differentiation, v.21 n.2, p.216-225, 2014. 
MANEECHOTESUWAN, $\mathrm{K}$. et al. Correction: Suppression of GATA-3 Nuclear Import and Phosphorylation: A Novel Mechanism of Corticosteroid Action in Allergic Disease. PLoS medicine, v.15 n.9, p. e1002657, 2018.

MARKOSKI M. M. Advances in the Use of Stem Cells in Veterinary Medicine: From Basic Research to Clinical Practice. Scientifica, v. 2016, Article ID 4516920, 2016.

MARSELLA R. An update on the treatment of canine atopic dermatitis. Veterinary medicine (Auckl), v.3, p.85-91, 2012.

MARSELLA, R. et al. Comparison of various treatment options for canine atopic dermatitis: a blinded, randomized, controlled study in a colony of research atopic beagle dogs. Veterinary dermatology, v.31 n.4, p. 284-e69, 2020.

MARSELLA, R.; DE BENEDETTO, A. Atopic Dermatitis in Animals and People: An Update and Comparative Review. Veterinary sciences, v.4 n.3, p.37, 2017.

MOYAERT, $\mathrm{H}$. et al. A blinded, randomized clinical trial evaluating the efficacy and safety of lokivetmab compared to ciclosporin in client-owned dogs with atopic dermatitis. Veterinary dermatology, v.28 n.6, p. 593-e145, 2017.

NAJAR, M. et al. Mesenchymal Stromal Cells and Immunomodulation: A Gathering Of Regulatory Immune Cells. Cytotherapy, V.18 N.2, P. 160-171, 2016.

NUTTALL, T. J. et al. Update on pathogenesis, diagnosis, and treatment of atopic dermatitis in dogs. Journal of the American Veterinary Medical Association, v.254 n.11, p. 1291-1300, 2019.
NUTTALL, T., REECE, D., ROBERTS, E. Life-long diseases need life-long treatment: long-term safety of ciclosporin in canine atopic dermatitis. The Veterinary record, n.174 Suppl 2(Suppl 2), 2014.

OLIVRY, T. et al. Early Activation of Th2/Th22 Inflammatory and Pruritogenic Pathways in Acute Canine Atopic Dermatitis Skin Lesions. The Journal of investigative dermatology, v.136 n.10, p. 1961-1969, 2016.

OLIVRY, T. et al. Treatment of canine atopic dermatitis: 2015 updated guidelines from the International Committee on Allergic Diseases of Animals (ICADA). BMC Veterinary Research, v.11 n.210, 2015.

OLIVRY, T. et al. Validation of the Canine Atopic Dermatitis Extent and Severity Index (CADESI)-4, a simplified severity scale for assessing skin lesions of atopic dermatitis in dogs. Veterinary dermatology, n.25 v.2, p.77-e25, 2014.

OLIVRY, T., WOFFORD, J., PAPS, J.S., DUNSTON, S.M. Stratum corneum removal facilitates experimental sensitization to mite allergens in atopic dogs. Veterinary Dermatology, v.22 n.2, p.188-196, 2011.

PALMEIRO B. S. Cyclosporine in veterinary dermatology. The Veterinary clinics of North America. Small animal practice, n.43 v.1, p.153-171, 2013.

PUCHEU-HASTON, C. M. et al. Review: Innate immunity, lipid metabolism and nutrition in canine atopic dermatitis. Veterinary dermatology, n.26 v.2, p.104e28, 2015b.

RAMOS F.O. et al. Canine atopic dermatitis attenuated by mesenchymal stem cells. 
Journal of advanced veterinary and animal research, n.7 v.3, p.554-565, 2020.

ROMANOV, Y. A. et al. Mesenchymal stem cells from human bone marrow and adipose tissue: isolation, characterization, and differentiation potentialities. Bulletin of experimental biology and medicine, n.140 v.1, p.138-143, 2005.

SAMSONRAJ, R. M. et al. Concise review: multifaceted characterization of human mesenchymal stem cells for use in regenerative medicine. Stem cells translational medicine, n.6 v.12, p.2173$2185,2017$.

SANTORO D. Therapies in Canine Atopic Dermatitis: An Update. Veterinary Clinics of North America: Small Animal Practice, v.49 n.1, p.9-26, 2019.

SANTORO, D. et al. Review: Pathogenesis of canine atopic dermatitis: skin barrier and host-micro-organism interaction. Veterinary dermatology, v.26 n.2, p. 84e25, 2015.

SARIDOMICHELAKIS, M. N., OLIVRY, T. An update on the treatment of canine atopic dermatitis. Veterinary journal (London, England: 1997), v.207, p.29-37, 2016.

SHIMADA, K. et al. Increased transepidermal water loss and decreased ceramide content in lesional and nonlesional skin of dogs with atopic dermatitis. Veterinary dermatology, v.20 n.5-6, p.541-546, 2009.

SOUZA, C. P. et al. A retrospective analysis of the use of lokivetmab in the management of allergic pruritus in a referral population of 135 dogs in the western USA. Veterinary dermatology, v.29 n.6, p. 489-e164, 2018.
STRIOGA, M. et al. Same or not the same? Comparison of adipose tissue-derived versus bone marrow-derived mesenchymal stem and stromal cells. Stem cells and development, v.21 n.14, p. 2724-2752, 2012.

TORRES, S. et al. Diverse bacterial communities exist on canine skin and are impacted by cohabitation and time. PeerJ, v.5, p.e3075, 2017.

VAN MEGEN, K. M. et al. Activated Mesenchymal Stromal Cells Process and Present Antigens Regulating Adaptive Immunity. Frontiers in immunology, v.10, p.694, 2019.

VILLATORO, A. J. et al. Allogeneic adipose-derived mesenchymal stem cell therapy in dogs with refractory atopic dermatitis: clinical efficacy and safety. The Veterinary record, v.183 n.21, p.645, 2018.

VISWANATHAN, S. et al. Mesenchymal stem versus stromal cells: international society for cell \& gene therapy (ISCT R) mesenchymal stromal cell committee position statement on nomenclature. Cytotherapy, v.21 n.10, p.1019-1024, 2019.

VOGA, M., ADAMIC, N., VENGUST, M., MAJDIC, G. Stem Cells in Veterinary Medicine-Current State and Treatment Options. Frontiers in veterinary science, v.7, p.278, 2020.

WANG, Y. et al. The Plasticity of Mesenchymal Stem Cells in Regulating Surface HLA-I. iScience, v.15, p.66-78, 2019.

WEI, X. et al. Mesenchymal stem cells: a new trend for cell therapy. Acta pharmacologica Sinica, v.34 n.6, p.747-754, 2013. 
WILLIAMS, J. T. et al. Cells isolated from adult human skeletal muscle capable of differentiating into multiple mesodermal phenotypes. American Journal of Surgery, v.65, n.1, p.22-26, 1999.

YAGI, H. et al. Mesenchymal stem cells: Mechanisms of immunomodulation and homing. Cell transplantation, v.19 n.6, p.667-79, 2010.

JASSIES-VAN DER LEE, A. et al. CD4+ and CD8+ skin-associated T lymphocytes in canine atopic dermatitis produce interleukin13, interleukin-22 and interferon- $\gamma$ and contain a CD25+ FoxP3+ subset. Veterinary dermatology, v. 25 n.5, p.456e72, 2014.

PUCHEU-HASTON, C. M. et al. Review: Lymphocytes, cytokines, chemokines and the T-helper 1-T-helper 2 balance in canine atopic dermatitis. Veterinary dermatology, v.26 n2, p.124-e32, 2015a.

MINESHIGE, T. et al. A study on periostin involvement in the pathophysiology of canine atopic skin. The Journal of veterinary medical science, v.80 n.1, p.103-11, 2018.

KLUKOWSKA-RÖTZLER, J. et al. Expression of thymic stromal lymphopoietin in canine atopic dermatitis. Veterinary dermatology, v.24 n.1, p.54-9.e9.0E14, 2013.

TAIT WOJNO, E. D., ARTIS, D. Emerging concepts and future challenges in innate lymphoid cell biology. The Journal of experimental medicine, v.213 n.11, p.2229-2248, 2016.

WILSON, A., HODGSON-GARMS, M., FRITH, J. E., GENEVER, P. Multiplicity of
Mesenchymal Stromal Cells: Finding the Right Route to Therapy. Frontiers in immunology, v..10, p.1112, 2019.

NAJAR, M., MARTEL-PELLETIER, J., PELLETIER, J. P., FAHMI, H. Mesenchymal Stromal Cell Immunology for Efficient and Safe Treatment of Osteoarthritis. Frontiers in cell and developmental biology, v.8, p.567813, 2020.

DEVIREDDY, L. R. et al. Questions and Challenges in the Development of Mesenchymal Stromal/Stem Cell-Based Therapies in Veterinary Medicine. Tissue engineering. Part B, Reviews, v.23 n.5, p.462-470, 2017. 